DOI: https://doi.org/10.24127/ajpm.v10i4.4210

\title{
PENGARUH KEMANDIRIAN BELAJAR DAN MOTIVASI BELAJAR MELALUI PEMBELAJARAN TPSQ TERHADAP KEMAMPUAN PEMAHAMAN KONSEP SISWA SMK
}

\author{
Rahmi $^{1}$, Hafizah Delyana ${ }^{2 *}$, Melisa ${ }^{3}$, Mulia Suryani ${ }^{4}$, Gusnita $^{5}$, \\ Miftahul Rizka ${ }^{6}$, Welly Apria ${ }^{7}$, Okky Rayhana $^{8}$ \\ $1,2 * 3,4,5,6,7,8$ Pendidikan Matematika, Universitas PGRI Sumatera Barat, Padang, Indonesia \\ *Corresponding author. \\ E-mail: $\quad$ rahmisajani@gmail.com $^{1)}$ \\ hafizahdelyana@gmail.com $^{2 *)}$ \\ icamelisa87@gmail.com ${ }^{3)}$ \\ $\underline{\text { muliasuryani@gmail.com }}^{4)}$ \\ gusnita138@gmail.com ${ }^{5)}$ \\ miftahulrizkal@gmail.com $^{6)}$ \\ apria571@gmail.com ${ }^{7}$ \\ okkyrayhana@gmail.com $^{8)}$
}

Received 10 September 2021; Received in revised form 17 November 2021; Accepted 27 December 2021

\begin{abstract}
Abstrak
Tujuan penelitian ini adalah untuk mengetahui bagaimana pengaruh kemandirian belajar dan motivasi belajar siswa terhadap kemampuan pemahaman konsep matematis siswa SMK melalui pembelajaran TPSq. Metode penelitian yang digunakan adalah survey dengan analisis korelasi dan regresi. Populasi pada penelitian ini adalah siswa SMK di Sumatera Barat, dengan jumlah sampel 25 orang siswa dengan teknik purporsive sampling. Data tentang kemandirian belajar dan motivasi belajar siswa diperoleh melalui angket, yaitu mengukur hal-hal yang berkaitan dengan duahal di atas. Sedangkan data kemampuan pemahaman konsep diperoleh melalui tes. Hasil analisa data diperoleh bahwa pengaruh kemandirian belajar dan motivasi belajar terhadap kemampuan pemahaman konsep ditunjukkan oleh koefisien korelasi sebesar 0,578 dan koefisien determinasi $\mathrm{R}^{2}$ sebesar 33,5\%, dan persamaan garis regresi $\hat{\mathbf{Y}}=35,648+0,296 \mathrm{X} \mathbf{1}+0,383 \mathrm{X} 2$. Melalui analisa pengujian diperoleh bahwa koefisen korelasi dan koefisien regresi tersebut signifikan. Hal tersebut membuktikan bahwa terdapat pengaruh kemandirian belajar dan motivasi belajar siswa secara bersama-sama terhadap kemampuan pemahaman konsep siswa.
\end{abstract}

Kata kunci: Kemampuan pemahaman konsep; kemandirian belajar; motivasi.

\begin{abstract}
The purpose of this study is to determine the extent of the effect of learning independence and student motivation to learn the ability to understand the concept of SMK's students through learning TPSq. The research method used was a survey with correlation and regression analysis. The population in this study were SMK's students in West Sumatra, with a total sample of 25 students using purporsive sampling techniques. Data about learning independence and student motivation are obtained through a questionnaire, which measures things related to the two things above. Whereas the data of concept comprehension ability was obtained through tests. The results of data analysis showed that the effect of learning independence and learning motivation on the ability to understand concepts is shown by a correlation coefficient of 0.578 and a determination coefficient of $\mathrm{R}^{2}$ of $33.5 \%$, and a regression line equation $\hat{\mathbf{Y}}=35,648+0,296 \times \mathbf{X}+0,383 \mathrm{X}_{2}$. Through analysis of the test it was found that the correlation coefficient and the regression coefficient were significant. This proves that there is an influence of learning independence and student learning motivation together on the ability to understand students' concepts.
\end{abstract}

Keywords: Ability to understand students' concepts; learning independence; motivation. 
DOI: https://doi.org/10.24127/ajpm.v10i4.4210

\section{PENDAHULUAN}

Pengajaran matematika sekolah merupakan salah satu cara dalam meningkatkan kualitas manusia karena penguasaan berpikir matematis akan memungkinkan salah satu jalan untuk menyusun pemikiran yang jelas, tepat dan teliti. Matematika sebagai ilmu banyak digunakan dalam bidang ilmu pengetahuan lain, terutama dalam perkembangan teknologi sekarang ini. Oleh karena itu, penguasaan matematika yang mendalam oleh peserta didik sangat diperlukan.(Sumarmo et al., 2012) mengungkapkan bahwa setiap orang dalam kegiatan hidupnya terlibat dengan matematika, mulai dari bentuknya yang sederhana dan rutin sampai pada bentuknya yang kompleks.

Secara garis besar, kemampuan dasar matematika menurut Sumarmo dalam (Sumaryati \& Sumarmo, 2013) diklasifikasikan atas: 1) Memahami konsep matematika, menjelaskan keterkaitan antar konsep dan mengaplikasikan konsep dan algoritma secara luwes, akurat, efisien, dan tepat dalam pemecahan masalah, 2) menggunakan penalaran pada pola dan sifat, melakukan manipulasi matematika dalam membuat generalisasi, menyusun bukti, atau menjelaskan gagasan dan pertanyaan matematika, 3) memecahkan masalah, 4) mengkomunikasikan gagasan dengan simbol, tabel, diagram atau media lain untuk memperjelas keadaan atau masalah, dan 5) memiliki sikap menghargai kegunaan matematika dalam kehidupan, sikap rasa ingin tahu, perhatian, dan minat dalam mempelajari matematika, serta sikap ulet dan percaya diri dalam pemecahan masalah. Sejalan dengan ini (Afriana et al., 2016; Sriwahyuni, 2019) menyatakan bahwa yang menjadi dasar bagi siswa dalam mengerjakan persoalan matematika adalah kemampuan pemahaman konsep. Artinya yang mnenjadi dasar atau focus dalam pembelajaran matematika pemahaman konsep.

Kenyataan yang ditemukan pada saat observasi, kemampuan pemahaman konsep yang dimiliki siswa saat ini masih belum menunjukkan adanya pemahaman konsep yang baik. Rendahnya kemampuan pemahaman konsep siswa terhadap matematika terlihat dari cara siswa dalam menyelesaikan soal-soal yang diberikan. Ini berkaitan erat dengan proses pembelajaran yang berlangsung di dalam kelas sehingga juga berpengaruh terhadap hasil belajar yang diperoleh siswa. Hal ini didukung oleh (Antika, 2019; Sipayung, 2018) yang menyatakan bahwa keberhasilan proses pembelajaran matematika dapat diukur dari tingkat pemahaman, pengusaan materi, dan prestasi belajar siswa. Selain itu, terdapat beberapa aspek kemampuan matematis yang harus dikuasai oleh siswa.

Berdasarkan hasil observasi diperoleh bahwa proses pembelajaran yang berlangsung di kelas masih berpusat pada guru, sehingga siswa masih cenderung pasif dalam pembelajaran. Apabila guru mengajukan pertanyaan kepada siswa hanya beberapa orang siswa yang berusaha menjawab, ini dikarenakan sebagian siswa belum bisa mengumpulkan informasi dari materi yang dipelajari. Siswa hanya menunggu jawaban teman tanpa berusaha mencari jawabannya terlebih dahulu ketika diberi latihan kemudian jawaban tersebut disalin tanpa dimengerti dan dipahami. Ini berarti kemandirian siswa dalam pembelajaran matematika masih rendah. Saat kegiatan pembelajaran berlangsung siswa juga terlihat melakukan aktivitas lain seperti 
berbicara dengan teman, berjalan-jalan di kelas, bahkan ada yang tertidur.

Siswa kurang percaya diri dalam membuatkan jawaban yang diperoleh jika diberi latihan. Siswa cenderung menanyakan kepada guru terkait jawaban yang diperolehnya. Selanjutnya ketika diberikan latihan yang sedikit berbeda dengan contoh siswa malas menyelesaikan soal tersebut. Ini juga menunjukkan belum optimalnya sikap fleksibilitas dan tekun dalam mengerjakan tugas matematika. Hal ini menunjukkan bahwa kemandirian belajar siswa masih rendah. Hal ini sejalan dengan (Hamdu \& Agustina, 2011; Manora et al., 2017) yang menyatakan siswa kurang termotivasi dalam belajar matematika karena siswa merasa matematika adalah pelajaran yang sangat sulit dan membosankan.Siswa malas untuk belajar di rumah dan hanya belajar pada saat ulangan saja. Siswa sering mengobrol mengenai hal-hal yang tidak berhubungan dengan pelajaran bersama teman sebangkunya, sehingga tujuan pembelajaran kurang tercapai. Selanjutnya, ketika diberikan latihan yang berbeda dengan contoh soal siswa malas menyelesaikannya. Ini menunjukkan belum optimalnya minat dan ketajaman serta keuletan siswa dalam belajar.

Hasil wawancara dengan guru bidang studi matematika kelas X SMK Negeri 1 Sintuk Toboh Gadang dan SMK Negeri 1 Bukit Sundi, diperoleh informasi bahwa siswa kurang memperhatikan guru saat menjelaskan pelajaran, dan siswa kurang termotivasi untuk aktif dalam mengemukakan ideide kreatif seperti menanggapi pertanyaan dari guru.

Menyikapi permasalahan di atas, perlu dilakukan usaha agar kemampuan afektif dan pemahaman konsep matematis siswa lebih baik. Salah satu model pembelajaran yang dapat diterapkan untuk mengatasi masalah tersebut adalah dengan menerapkan model pembelajaran kooperatif tipe Think Pair Square. Strategi Think Pair Square merupakan salah satu strategi yang memberi kesempatan pada siswa untuk bekerja sendiri serta bekerja sama dengan orang lain dan bertujuan untuk meningkatkan kemampuan berpikir, komunikasi, dan mendorong siswa untuk berbagi informasi dengan siswa lain (Sumaryati \& Sumarmo, 2013). Secara psikologis, siswa akan lebih merasa nyaman bertanya ataupun berdiskusi dengan sesamanya.

Berdasarkan masalah yang diuraikan di atas maka tujuan penelitian ini adalah untuk mengetahui apakah terdapat pengaruh kemandirian belajar dan motivasi belajar melalui pembelajaran $T P S q$ terhadap kemampuan pemahaman konsep siswa SMK.

\section{METODE PENELITIAN}

Penelitian ini merupakan penelitian eksperimen yang menggunakan pendekatan kuantitatif, dengan metode survei dan teknik korelasional yang menggambarkan tentang variabel-variabel yang diteliti, serta menyelidiki hubungan antarvariabel. Penelitian dilakukan untuk mengungkap pengaruh dari beberapa variable yang diantaranya kemandirian belajar dan motivasi terhadap kemampuan pemahaman konsep siswa.

Teknik pengambilan sampel menggunakan Purporsive sampling. Sampel yang dipilih adalah 25 orang siswa yang berasal dari kelas X SMK Negeri 1 Bukit Sundi Kabupaten Solok dan Sintuk Toboh Gadang Kabupaten Padang Pariaman. Berdasarkan hasil 
observasi awal dan wawancara dengan guru matematika diketahui bahwa kemampuan pemahaman konsep siswa masih rendah. Di samping itu kemandirian belajar dan motivasi siswa tersebut masih lemah. Instrumen yang digunakan adalah tes dan angket. Tes yang digunakan berbentuk essay dan memuat indikator kemampuan pemahaman konsep, sedangkan angket kemandirian terdiri atas 28 butir pernyataan yang memuat 9 indikator kemandirian belajar dan angket motivasi yang terdiri atas 46 butir pernyataan yang memuat 5 indikator.

Teknik analisis data yang digunakan adalah regresi linier berganda dan uji F. Langkah pertama adalah menganalisis skor angket kemandirian belajar yang dilakukan dengan menentukan jumlah skor yang diperoleh masing-masing mahasiswa terlebih dahulu. Jumlah skor yang diperoleh kemudian dibagi dengan jumlah skor maksimum angket dan dikali dengan $100 \%$ untuk mendapatkan persentase skor kemandirian belajar.

Langkah kedua adalah menganalisis skor angket motivasi belajar yang dilakukan dengan menentukan jumlah skor yang diperoleh masing-masing mahasiswa terlebih dahulu. Perhitungannya hampir sama dengan data kemandirianbelajar.

Langkah ketiga adalah menganalisis data tes yang dilakukan untuk memperoleh informasi tentang kemampuan pemahaman konsep siswa. Tes dinilai menggunakan rubrik kemampuan pemahaman konsep yang telah ditentukan. Selanjutnya teknik analisis data untuk melihat hubungan kemandirian belajar dan motivasi belajar terhadap kemampuan pemahaman konsep siswa menggunakan analisis regresi linear berganda dengan model sebagai berikut:

$$
Y=a+b X_{1}+c X_{2}
$$

Keterangan:

$Y \quad$ : Tes akhir hasil belajar siswa

$a$ : harga $Y$ bila $X=0$ (harga konstan)

$b, c$ : angka arah atau koefisien regresi, yang menunjukan angka peningkatan atau penurunan variabel dependen yang didasarkan pada variabel independen

$\mathrm{X}_{1}$ : skor angket kemandirian belajar

$\mathrm{X}_{2} \quad$ : skor angket motivasi

Keeratan hubungan linier antara $X_{1}, X_{2}$ dan $Y$ dapat dilihat dari koefisien korelasi. Korelasi ganda adalah suatu nilai yang memberika kuatnya pengaruh atau hubungan dua variabel atau lebih secara bersama sama dengan variabel lain. Menurut Suyono (2015, 92), Rumus koefisien korelasi berganda adalah sebagai berikut.

$R_{y . x_{1} x_{2}}=\sqrt{\frac{r^{2} y x_{1}+r^{2} y x_{2}-2 r_{y x_{1}} r_{y x_{2}} r_{x_{1} x_{2}}}{1-r^{2} x_{1} x_{2}}}$

\section{HASIL DAN PEMBAHASAN}

Kemandirian siswa dalam proses pembelajaran dengan model TPSq dapat dilihat dari angket kemandirian yang dibagikan pada responden sebanyak 25 orang siswa SMK dari kelas X SMK Negeri 1 Bukit Sundi Kabupaten Solok dan Sintuk Toboh Gadang Kabupaten Padang Pariaman. Indikator kemandirian belajar dalam penelitian ini adalah; (1) insiatif dan motivasi belajar instrinsik, (2) kebiasaan mendiagnosa kebutuhan belajar, (3) menetapkan tujuan/target belajar, (4) memonitor, mengatur, dan mengontrolbelajar, (5) memandang kesulitan sebagai tantangan; (6) memanfaatkan dan mencari sumber yang relevan, (7) memilih, menerapkan 
DOI: https://doi.org/10.24127/ajpm.v10i4.4210

strategi belajar, (8) mengevaluasi proses dan hasil belajar, dan (9) Self efficacy/ konsepdiri/ kemampuan diri.
Tingkat kemandirian belajar mahasiswa dapat dilihat dari persentase dari setiap indikator yang disajikan pada Tabel 1.

Tabel 1. Persentase perindikator kemandirian belajar

\begin{tabular}{clcc}
\hline No & \multicolumn{1}{c}{ Indikator Kemandirian Belajar } & Skor $(\boldsymbol{\%})$ & Kriteria \\
\hline 1 & Insiatif dan motivasi belajar instrinsik & 62,93 & Kuat \\
2 & Kebiasaan mendiagnosa kebutuhan belajar & 63,51 & Kuat \\
3 & Menetapkan tujuan/ target belajar & 64,66 & Kuat \\
4 & Memonitor, mengatur, dan mengontrol belajar & 63,79 & Kuat \\
5 & Memandang kesulitan sebagai tantangan & 62,93 & Kuat \\
6 & Memanfaatkan dan mencari sumber yang relevan & 59,05 & Kuat \\
7 & Memilih, menerapkan strategi belajar & 62,50 & Kuat \\
8 & Mengevaluasi proses dan hasil belajar & 63,51 & Kuat \\
9 & Self efficacy/ konsepdiri/ kemampuan diri. & 61,70 & Kuat \\
\hline
\end{tabular}

Berdasarkan Tabel 1 terlihat
bahwa persentase kemandirian belajar siswa berada pada interval $50 \%-75 \%$. Jika diinterpretasikan maka indikator kemandirian belajar siswa termasuk ke kriteria Kuat. Hasil persentase kemandirian yang diperoleh diperkuat oleh Hal ini juga diperkuat oleh (Ambiyar et al., 2020; Effendi et al., 2018; Yanti \& Surya, 2017) yang mengatakan bahwa satu sub-faktor penting dari keadaan individu yang mempengaruhi belajar seseorang adalah kemandirian belajar.

Hal ini sejalan dengan ungkapan (Afriyola et al., 2020; Gusnita et al., 2021) bahwa kemandirian belajar akan terwujud jika mahasiswa aktif mengontrol sendiri segala sesuatu yang dikerjakan, mengevaluasi dan selanjutnya merencanakan sesuatu yang lebih dalam pembelajaran dan mahasiswa juga mau terlibat aktif dalam proses pembelajaran.

Kemandirian belajar merupakan salah satu aspek yang dapat memberikan pengaruh terhadap kualitas pembelajaran. Karena kemadirian belajar membuat siswa dapat mengerjakan segala sesuatu sesuai dengan kemampuan yang dimilikinya secara optimal dan tidak menggantungkan diri kepada orang lain. Siswa yang memiliki kemandirian belajar yang tinggi akan berusaha menyelesaikan segala latihan atau tugas yang diberikan oleh guru dengan kemampuan yang dimilikinya sendiri, (Ambiyar et al., 2020; Badrulaini, 2018; Rahmi, 2016).

Motivasi belajar siswa dalam proses pembelajaran dengan model $T P S q$ dapat dilihat dari angket kemandirian yang dibagikan pada responden sebanyak 25 orang siswa SMK Negeri 1 Bukit Sundi Kabupaten Solok dan Sintuk Toboh Gadang Kabupaten Padang Pariaman. Indikator motivasi belajar dalam penelitian ini adalah:(1) ketekunan dalam belajar; (2) ulet dalam menghadapi kesulitan; (3) minat dan ketajaman perhatian belajar; (4) berprestasi dalam belajar; dan (5) mandiri dalam belajar.skor motivasi belajar siswa per indikator dapat dilihat pada Tabel 2. 
DOI: https://doi.org/10.24127/ajpm.v10i4.4210

Tabel 2. Kriteria skor motivasi belajar siswa per indikator

\begin{tabular}{clcc}
\hline No & \multicolumn{1}{c}{ Indikator } & Skor $(\%)$ & Kriteria \\
\hline 1 & Ketekunan dalam belajar & 82,8 & Sangat Kuat \\
2 & Ulet dalam menghadapi kesulitan & 70,48 & Kuat \\
3 & Minat dan ketajaman perhatian belajar & 82,2 & Sangat Kuat \\
4 & Berprestasi dalam belajar & 77,51 & Kuat \\
5 & Mandiri dalam belajar & 68,78 & Kuat \\
\hline
\end{tabular}

Tabel 2 menunjukkan bahwa pembelajaran TPSq dapat memunculkan motivasi belajar siswa ini terlihat dari kriteria motivasi perindikator yang berada pada criteria kuat dan bahkan sangat kuat. Hasil ini sejalan dengan penelitian (Rahmi \& Rayhana, 2020) yang menyimpulkan bahwa pembelajaran Think Pair Square dapat menumbuhkan motivasi siswa dalam belajar matematika

Pelaksanaan tes diikuti oleh 25 orang siswa. Selanjutnya data tesakhir dianalisis untuk mengetahui nilai kemampuan pemahaman konsep siswa. Indikator kemampuan pemahaman konsep siswa yang ditinjau adalah kemampuan yang dimiliki siswa dalam memahami, mengelompokkan, mengidentifikasi, menafsirkan, dan menyimpulkan suatu persoalan matematika sehingga mampu menyelesaikannya dengan baik dan benar.

Hipotesis dari penelitian ini adalah terdapat pengaruh kemandirian belajar $\left(\mathrm{X}_{1}\right)$ dan motivasi belajar $\left(\mathrm{X}_{2}\right)$ secara bersama-sama terhadap kemampuan pemahaman konsep siswa (Y). Untuk membuktikan hipotesis tersebut, digunakan hasil perhitungan yang dilakukan dengan bantuan computer melalui program aplikasi SPSS 17.0. Hasil perhitungan dapat dilihat pada Tabel 3.

Tabel 3. Hasil perhitungan koefisien korelasi pengaruh variabel $X_{1}$ dan $X_{2}$ terhadap variabel Y

\begin{tabular}{ccccc}
\hline Model & $\mathrm{R}$ & R Square & Adjusted R Square & Std. Error of the estimate \\
\hline 1 & $.578^{\mathrm{a}}$ & .335 & .274 & 5,494 \\
\hline
\end{tabular}

a. Predictors: (Constant), Motovasi (X2), Kemandirian (X1)

Dari Tabel 3, terlihat bahwa koefisien korelasi ganda dari pengaruh variable bebas kemandirian belajar $\left(\mathrm{X}_{1}\right)$ dan motivasi belajar $\left(\mathrm{X}_{2}\right)$ secara bersama-sama terhadap kemampuan pemahaman konsep siswa adalah sebesar 0,578. Dari perhitungan tersebu diperoleh bahwa koefisien korelasi tersebut signifikan, dengan kata lain bahwa terdapat pengaruh yang signifikan variable bebas motivasibelajar (X1) dan kemandirian belajar (X2) secara bersama-sama terhadap kemampuan pemahaman konsep siswa (Y).

Sedangkan

koefisien determinasinya adalah sebesar $33,5 \%$ menunjukkan bahwa besarnya kontribusi kemandirian belajar $\left(\mathrm{X}_{1}\right)$ dan motivasi belajar $\left(\mathrm{X}_{2}\right)$ secara bersamasama terhadap kemampuan pemahaman konsep siswa adalah sebesar 33,5\%, sisanya $(66,5 \%)$ karena pengaruh factor lain. 
DOI: https://doi.org/10.24127/ajpm.v10i4.4210

Tabel 4. Rekapitulasi hasil perhitungan persamaan garis regresi pengaruhvariabel X1 dan X2 terhadap variabel Y

\begin{tabular}{|c|c|c|c|c|c|c|}
\hline \multicolumn{7}{|c|}{ Coefficients $^{\mathrm{a}}$} \\
\hline \multirow{2}{*}{\multicolumn{2}{|c|}{ Model }} & \multicolumn{2}{|c|}{ Coefficients } & $\begin{array}{l}\text { Standardized } \\
\text { Coefficients }\end{array}$ & \multirow[b]{2}{*}{$\mathrm{t}$} & \multirow[b]{2}{*}{ Sig. } \\
\hline & & B & Std. Error & Beta & & \\
\hline 1 & (Constant) & 35.648 & 17.171 & & 2.076 & .050 \\
\hline & Kemandirian (X1) & .296 & .171 & .308 & 1.738 & .096 \\
\hline & Motivasi (X2) & .383 & .123 & .551 & 3.112 & .005 \\
\hline
\end{tabular}

a. DependentVariable: Tes (Y)

Tabel 5. Rekapitulasi hasil perhitungan pengujian signifikasi koefisien regresi pengaruhvariabel $\mathrm{X} 1$ dan $\mathrm{X}_{2}$ terhadap variabel $\mathrm{Y}$

\begin{tabular}{llrrrrr}
\hline \multicolumn{7}{c}{ ANOVA $^{\mathbf{a}}$} \\
\hline Model & \multicolumn{1}{c}{ Sum of Squares } & df & MeanSquare & F & \multicolumn{1}{c}{ Sig. } \\
\hline \multirow{2}{*}{1} & Regression & 333.815 & 2 & 166.908 & 5.531 & $.011^{\mathrm{b}}$ \\
\cline { 2 - 7 } & Residual & 663.945 & 22 & 30.179 & & \\
\cline { 2 - 7 } & Total & 997.760 & 24 & & & \\
\hline
\end{tabular}

a. DependentVariable: Tes (Y)

b. Predictors: (Constant), Motivasi (X2), Kemandirian (X1)

Untuk pengujian hipotesis melalui analisis regresi diperoleh hasil perhitungan terlihat pada Tabel 4 dan Tabel 5. Dari Tabel 4 diperoleh persamaan garis regresi yang merepresentasikan pengaruh variabel $\mathrm{X}_{1}$ dan $\mathrm{X}_{2}$ terdahap variabel $\mathrm{Y}$, yaitu:

$$
Y=35,648+0,296 X_{1}+0,383 X_{2}
$$

Nilai konstanta $(35,648)$ menunjukkan bahwa dengan kemandirian dan motivasi belajar rendah, sulit bagi siswa tersebut untuk bisa meraih hasil belajar yang baik, sedangkan nilai koefisien regresi (0,296 dan 0,383) menunjukkan adanya pengaruh positif kemandirian belajar (X1) dan motivasi belajar (X2) secarabersama-sama terhadap variable terikat kemampuan pemahaman konsep siswa (Y). Angka koefisien regresi tersebut juga menunjukkan bahwa setiap kenaikan satu nilai kemandirian belajar maka terdapat kenaikan kemampuan pemahaman konsep sebesar 0,296, dan setiap ada kenaikan satu nilai motivasi belajar maka akan terdapat kenaikan hasil belajar sebesar 0,383 .
Pengujian signifikansi gari regresi tersebut adalah dengan memperhatikan hasil perhitungan yang ada pada Tabel 5. Menurut ketentuan yang ada, kriteria signifikansi regresi tersebut adalah"jika Sig < 0.05 maka $\mathrm{H}_{0}$ ditolak" atau "jika Fhitung> Ftabel maka $\mathrm{H}_{0}$ ditolak", yang berarti bahwa koefisien regresi tersebut signifikan, dengan kata lain terdapat pengaruh yang signifikan variable bebas $\mathrm{X}_{1}$ dan $\mathrm{X}_{2}$ terhadap variable terikat Y. Nilai Sig adalah bilangan yang tertera pada kolom Sig dalam Tabel 5. Nilai Fhitung adalah bilangan yang tertera pada kolomF dalam Tabel 5. Dari Tabel 5, terlihat bahwa nilai Sig=0.011 dan $\mathbf{F}_{\text {hitung }}=5,531$, sedangkan $\mathbf{F}_{\text {tabel }}=4,28$. Karena nilai Sig $<0,05$ dan $\mathbf{F}_{\text {hitung }}>\mathbf{F}_{\text {tabel }}$ maka $\mathrm{H}_{0}$ ditolak yang berarti bahwa koefisien regresi tersebut signifikan. Dengan kata lain bahwa terdapat pengaruh variable bebas kemandirianbelajar $\left(\mathrm{X}_{1}\right)$ dan motivasibelajar $\left(\mathrm{X}_{2}\right)$ secara bersamasama terhadap kemampuan pemahaman konsep siswa (Y). 
DOI: https://doi.org/10.24127/ajpm.v10i4.4210

Dari hasil pengujian korelasi maupun pengujian regresi tersebut maka bisa disimpulkan bahwa terdapat pengaruh yang signifikan variable bebas kemandirian belajar $\left(\mathrm{X}_{1}\right)$ dan motivasi belajar $\left(\mathrm{X}_{2}\right)$ secarabersamasama terhadap variable terikat kemampuan pemahaman konsep siswa (Y).

Dari deskripsi data setelah dilakukan analisis korelasi diperoleh koefisien korelasi sebesar 0,578 dan koefisien determinasi sebesar 33,5\%, setelah dilakukan pengujian dengan program SPSS terbukti bahwa koefisien korelasi tersebut signifikan. Hal ini berarti bahwa terdapat pengaruh variable bebas kemandirian belajar (X1) dan motivasi belajar (X2) secara bersama-sama terhadap variable terikat kemampuan pemahaman konsep siswa (Y).

Hal ini didukung oleh penelitian yang dilakukan (Rahmi \& Rayhana, 2020) yang menyatakan bahwa pembelajaran menggunakan model kooperatif tipe Think Pair Square memotivasi siswa agar lebih tekun dalam belajar. Sebagian besar siswa hadir di sekolah sebelum bel berbunyi, rajin untuk datang ke sekolah, merasa rugi jika tidak masuk sekolah, cenderung masuk ke kelas jika guru telah datang dan berusaha untuk selalu hadir di sekolah.

Pada model pembelajaran kooperatif tipe Think Pair Square, siswa saling berdiskusi untuk menemukan atau memahami konsep dan memikirkan pekerjaannya satu sama lain. Model pembelajaran kooperatif tipe Think Pair Square lebih menekankan pada kelompok, dan kesempatan yang sama untuk berbagi hasil bagi setiap anggota. Penekanan terhadap hal tersebut diharapkan dapat mendorong siswa berusaha memberikan yang terbaik dalam kelompoknya (Afriana et al., 2016).

Berdasarkan hasil penelitian yang telah dilakukan (Warniasih, 2017) menyatakan bahwa Model pembelajaran kooperatif Think Pair Square efektif digunakan dalam meningkatkan kemampuan pemahaman konsep materi pendugaan parameter mahasiswa semester IV Prodi Pendidikan Matematika UPY. Penelitian yang dilakukan oleh (Mulyadi, 2018) menunjukkan bahwa ada perbedaan yang singnifikan dalam kemandirian siswa tetapi tidak ada perbedaan dalam hasil belajar dari domain pengetahuan dan keterampilan siswa.

Pembelajaran matematika adalah upaya membantu siswa untuk mengkontruksi konsep-konsep atau prinsip-prinsip matematika dengan kemampuannya sendiri melalui proses internalisasi sehingga konsep atau prinsip itu terbangun kembali (Amer \& Alnaja, 2017; Kistian, 2019). Berdasarkan uraian tersebut, dapat disimpulkan bahwa pembelajaran matematika lebih menekankan kepada bagaimana upaya guru mendorong siswau ntuk menemukan dan mengembangkan konsep-konsep matematika dengan sendiri sehingga informasi yang diperoleh dapat di pahami dengan baik.

Ranah afektif adalah ranah yang berhubungan dengan sikap, nilai, perasaan, emosi serta derajat penerimaan atau penolakan suatu obyek dlam kegiatan belajar mengajar. (Samura, 2015) membagi ranah afektif menjadi 5 kategori yaitu : 1) Receiving/ Attending/ Penerimaan; 2) Responding/ Menanggapi; 3) Valuing/ Penilaian; 4) Organization/ Organisasi/ Mengelola; dan 5) Characterization/ Karakteristik. 
DOI: https://doi.org/10.24127/ajpm.v10i4.4210

Pada penelitian ini sikap yang diamati adalah: kemandirian belajar dan motivasi belajar. Kemandirian belajar sebagai proses perancangan dan pemantauan diri yang seksama terhadap proses kognitif dan afektif dalam menyelesaikan suatu tugas akademik, (Asmar \& Delyana, 2020; Egok, 2016). (Asy'ari et al., 2015) mendefinisikan kemandirian belajar sebagai kemampuan perilaku sendiri, dan merupakan kerja keras personalitas manusia. Sedangkan menurut Zimerman dalam (Pratiwi \& Laksmiwati, 2016) kemandirian belajar merupakan suatu proses belajar yang berorientasi pada pencapaian sebuah tujuan.

Selanjutnya menurut (Hamdu \& Agustina, 2011) pada dasarnya motivasi adalah suatu usaha yang disadari untuk menggerakkan, menggarahkan, dan menjaga tingkah laku seseorang agar ia terdorong untuk bertindak melakukan sesuatu sehingga mencapai hasil atau tujuan tertentu. Sejalan dengan hal ini (Rahmi \& Rayhana, 2020) mengungkapkan salah satu sikap yang diperlukan siswa untuk mencapai tujuan pembelajaran adalah motivasi. (Manora et al., 2017) melaporkan bahwa siswa yang memiliki motivasi internal akan selalu bersemangat dalam mengikuti semua mata pelajaran tanpa adanya paksaan.Motivasi eksternal diperoleh siswa dengan adanya ajakan, suruhan, atau paksaan dari orang lain yang menyebabkan siswa belajar.

Hasil penelitian (Antika, 2019; Sumaryati \& Sumarmo, 2013) menunjukkan bahwa Think Pair Square dapat meningkatkan kemampuan pemahaman konsep mahasiswa. Senada dengan hal itu ( $\mathrm{J}$ et al., 2012) juga menyatakan bahwa tipe Think Pair Square lebih baik daripada pemahaman konsep matematis siswa yang menerapkan konvensional. (Rayhana et al., 2019) pada penelitiannya menyimpulkan bahwa pemahaman konsep matematis siswa setelah diterapkan Think Pair Square lebih baik daripada sebelum diterapkan Think Pair Square.

Sebagaimana (Utami et al., 2017) menyatakan bahwa motivasi merupakan salah satu faktor yang ikut berpengaruh terhadap efektivitas pembelajaran. Proses pembelajaran memerlukan adanya motivasi. Motivasi akan menggerakkan siswa untuk melakukan sesuatu. Kaitannya dengan proses pembelajaran, motivasi akan menggerakkan siswa untuk melakukan kegiatan belajar.

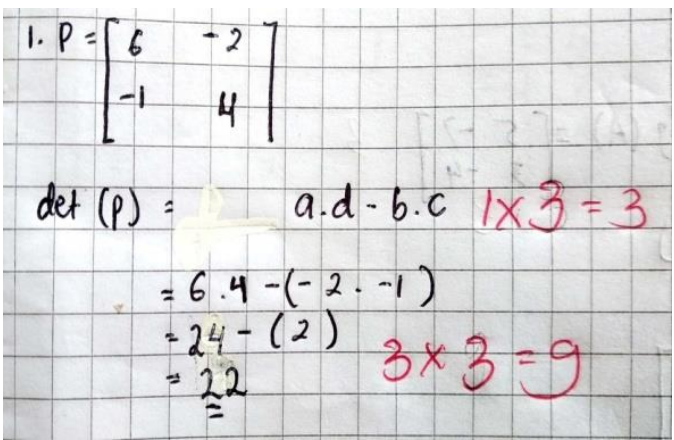

Gambar 1. Lembar jawaban tes siswa dengan kemandirian yang kuat

Gambar 1 terlihat bahwa siswa jelas dan tepat dalam menyatakan ulang sebuah konsep. Siswa memperoleh skor maksimum yaitu 3. Gambar tersebut juga menunjukan bahwa siswa lengkap dan tepat dalam mengaplikasikan konsep atau algoritma pemecahan masalah. Siswa memperoleh skor maksimum yaitu 9. Pada tes ini siswa sudah mampu menjawab semua soal dengan baik. Hal ini menunjukkan bahwa pemahaman konsep siswa baik. Hal ini sejalan dengan penelitian (Antika, 2019; Asy'ari et al., 2015; Rayhana et al., 2019) menyatakan bahwa adanya pengaruh penerapan model pembelajaran kooperatif tipe 
think pair square terhadap pemahaman konsep siswa.

Terkait dengan pemahaman (Zuraida, Johar, 2013) menyatakan bahwa siswa akan mencapai pemahaman yang bermakna apabila dapat mengubah informasi yang ada dalam pikirannya ke bentuk lain yang lebih berarti. Selain itu, (Latif, 2017; Sari, 2019; Utami et al., 2017) menyatakan bahwa pada umumnya pada proses pembelajaran matematika banyak diantara siswa merasa kesulitan untuk menerima dan mencerna materimateri yang disajikan. Hal yang demikian dapat disebabkan oleh beberapa faktor antara lain, kompetensi guru, metode yang digunakan, serta sarana penunjang.

Berdasarkan uraian pembahasan diatas diperoleh hasil bahwa terdapat pengaruh yang positif dan sangat signifikan antara kemandirian belajar dan motivasi belajar siswa

\section{KESIMPULAN}

Berdasarkan deskripsi data penelitian dan setelah dilakukan analisis data angket kemandirian belajar, motivasi dan tes kemampuan pemahaman konsep siswa, hasil penelitian ini dapat disimpulkan sebagai berikut. Terdapat pengaruh yang positif dan sangat signifikan kemandirian belajar (X1) dan motivasi belajar (X2) secara bersama-sama terhadap variable terikat kemampuan pemahaman konsep siswa. Hal ini dibuktikan oleh hasil pengujian hipotesis melalui analisis regresi ganda diperoleh bahwa nilai Sig $=0.011$ dan $\mathrm{F}$ hitung $=5,531$, sedangkan $F_{\text {tabel }}=4,28$ sehingga nilai Sig $<0,05$ dan $\mathbf{F}$ hitung $>\mathbf{F}$ tabel yang berarti regresi tersebut signifikan. Oleh karena itu, dapat disimpulkan bahwa terdapat pengaruh kemandirian belajar dan motivasi belajar melalui pembelajaran
$T P S q$ terhadap kemampuan pemahaman konsep siswa SMK.

Pada penelitian selanjutkan diharapkan bisa melihat variablevariabel afektif dan kognitif yang lain, seperti: self efficiacy, self concept, dan lainnya.

\section{DAFTAR PUSTAKA}

Afriana, L., Aima, Z., \& Muslim, A. P. (2016). PENGARUH PENERAPAN MODEL PEMBELAJARAN KOOPERATIF TIPE THINK PAIR SQUARE TERHADAP PEMAHAMAN KONSEP MATEMATIS SISWA KELAS VIII SMPN 3 KOTO XI TARUSAN PESISIR SELATAN.

Afriyola, F., Rahmi, R., \& Delyana, H. (2020). PENGARUH KEMANDIRIAN BELAJAR TERHADAP HASIL BELAJAR MATEMATIKA SISWA MELALUI PENERAPAN PEMBELAJARAN KOOPERATIF TIPE THINK PAIR SHARE. $A l$ Khawarizmi: Jurnal Pendidikan Dan Pembelajaran Matematika, 28(12), 1286-1290.

Ambiyar, A., Aziz, I., \& Delyana, H. (2020). Hubungan Kemandirian Belajar dengan Kemampuan Pemecahan Masalah Matematis. Jurnal Pendidikan Matematika, 11(1), 1. https://doi.org/10.36709/jpm.v11i1. 9638

Amer, M., \& Alnaja, F. A. (2017). ELearning Application to Teaching Mathematics E-LEARNING APPLICATION TO TEACHING MATHEMATICS. International Journal of Management and Applied Science, 3(9), 81-90.

Antika. (2019). Pengaruh Penerapan Model Pembelajaran Kooperatif Tipe Think- Pair-Square terhadap Kemampuan Pemahaman Konsep Matematis ditinjau dari 
DOI: https://doi.org/10.24127/ajpm.v10i4.4210

Kemampuan Awal Matematika Siswa SMP. Juring (Journal for in Mathematics Learning), 2(2), 118129.

Asmar, A., \& Delyana, H. (2020). Hubungan Kemandirian Belajar Terhadap Kemampuan Berpikir Kritis Melalui Penggunaan Software Geogebra. AKSIOMA: Jurnal Program Studi Pendidikan Matematika, 9(2), 221-230. https://doi.org/10.24127/ajpm.v9i2. 2758

Asy'ari, Usodo, B., \& Riyadi. (2015). EKSPERIMENTASI MODEL PEMBELAJARAN KOOPERATIF TIPE THINK PAIR SQUARE DENGAN METODE QUESTION STUDENT HAVE DAN THINK TALK WRITE PADA POKOK BAHASAN BANGUN RUANG DITINJAU

DARI KEMANDIRIAN BELAJAR SISWA KELAS VIII SMP NEGERI SE-KABUPATEN. Jurnal Elektronik Pembelajaran Matematika, 3(1), 27-37.

Badrulaini. (2018). Hubungan kemampuan pemecahan masalah dan kemandirian belajar terhadap hasil belajar matematika peserta didik. Jurnal Pendidikan Tambusai, 2(4), 847-855. https://jptam.org/index.php/jptam/a rticle/download/32/28

Effendi, Mursilah, \& Mujiono. (2018). Korelasi Tingkat Perhatian Orang Tua dan Kemandirian Belajar dengan Prestasi Belajar Siswa. Jurnal Ilmiah Multi Sciences, 10(1), 17-23.

Egok. (2016). Kemampuan Berpikir Kritis dan Kemandirian Belajar dengan Hasil Belajar Matematika. Journal of Chemical Information and Modeling, 53(9), 1689-1699. https://doi.org/10.1017/CBO97811 07415324.004

Gusnita, G., Melisa, M., \& Delyana, H.
(2021). Kemandirian Belajar Siswa Melalui Model Pembelajaran Kooperatif Think Pair Square (TPSq). Jurnal Absis: Jurnal Pendidikan Matematika Dan Matematika, 3(2), 286-296.

Hamdu, G., \& Agustina, L. (2011). Pengaruh Motivasi Belajar Siswa terhadap Pestasi Belajar IPA di Sekolah Dasar. Jurnal Penelitian Pendidikan, 12(1), 82-83.

J, M. W., Rizal, Y., \& Nilawasti. (2012). Model Cooperative Learning Tipe Think Pair Square Dalam. Jurnal Pendidikan Matematika, 1(1), 36.

Kistian, A. (2019). Penerapan Model Pembelajaran Problem Based Learning (PBL) dalam Meningkatkan Hasil Belajar Siswa Kelas IV SD Negeri Ujong Tanjong Kabupaten Aceh Barat. Genta Mulia, X(1), 92-104.

Latif, S. (2017). Mathematical Connection Ability in Solving Mathematics Problem Based on Initial Abilities of Students At Smpn 10 Bulukumba. Jurnal Daya Matematis, $4(2), \quad 207$. https://doi.org/10.26858/jds.v4i2.28 99

Lestari, K. E. K. A., \& Kunci, K. (2014). IMPLEMENTASI BRAIN-BASED LEARNING UNTUK MENINGKATKAN KEMAMPUAN KONEKSI DAN KEMAMPUAN BERPIKIR KRITIS SERTA MOTIVASI BELAJAR SISWA SMP. 2(1), 38 .

Manora, yupi A., Usodo, B., \& Pramudya, I. (2017). Upaya Meningkatkan Motivasi Belajar Matematika melalui Model Pembelajaran ARIAS (Assurance, Relevance, Interest, Assessment, Satisfaction) Pada Siswa Kelas VIII H SMP Negeri 2 Mojolaban Tahun Pelajaran 2016/2017. Jurnal Pendidikan Matematika Dan Matematika, 1(4), 56-58. 
Pratiwi, I. D., \& Laksmiwati, H. (2016). Kepercayaan Diri dan Kemandirian Belajar Pada Siswa SMA Negeri "X." Jurnal Psikologi Teori Dan Terapan, 7(1), 43-49.

Rahmi. (2016). PENINGKATAN KEMANDIRIAN BELAJAR MAHASISWA PADA MATA KULIAH KALKULUS DIFERENSIAL. Lemma, III(1), 31-42.

Rahmi, \& Rayhana, O. (2020). Analisis Motivasi Belajar Siswa melalui Pembelajaran Think Pair Square. Jurnal Pendidikan Matematika Raflesia, 05(02), 26-39.

Rayhana, O. ; Rahmi, R., \& Suryani, M. (2019).

PENGARUH PENERAPAN THINK PAIR SQUARE TERHADAP PEMAHAMAN KONSEP MATEMATIS. PROSIDING SEMINAR NASIONAL STKIP PGRI SUMATERA BARAT, 5(1), 222-230.

Samura, A. O. (2015). Penggunaan media dalam pembelajaran matematika dan manfaatnya. Delta-Pi: Jurnal Matematika Dan Pendidikan Matematika, 4(1), 69-79.

Sari, D. M. (2019). Kemampuan Pemahaman Konsep Matematis Ditinjau Dari Self Efficacy Siswa Dan Model Pembelajaran Think Pair Share (Tps) Di Smp Negeri 20 Palembang. 12(1).

Sipayung, A. (2018). Meningkatkan Pemahaman Konsep Matematika tentang Sifat-Sifat Bangun Ruang Sederhana melalui Contextual Teaching and Learning. Mosharafa: Jurnal Pendidikan Matematika, 7(3), 401-412. https://doi.org/10.31980/mosharafa. v7i3.153

Sriwahyuni, T. (2019). ANALISIS KEMAMPUAN KOMUNIKASI MATEMATIS SISWA SMP PADA MATERI SEGIEMPAT
DAN SEGITIGA. Jurnal Kajian Pembelajaran Matematika, 3(April), 18-23.

Sumarmo, U., Hidayat, W., Zukarnaen, R., Hamidah, M., \& Sariningsih, R. (2012). KEMAMPUAN DAN DISPOSISI BERPIKIR LOGIS, KRITIS, DAN KREATIF MATEMATIK (Eksperimen terhadap Siswa SMA Menggunakan Pembelajaran Berbasis Masalah dan Strategi Think-Talk-Write). Jurnal Pengajaran Matematika Dan Ilmu Pengetahuan Alam, 17(1), 17. https://doi.org/10.18269/jpmipa.v17 i1.228

Sumaryati, E., \& Sumarmo, U. (2013). Pendekatan Induktif-Deduktif Disertai Strategi Think Pair Square Untuk Meningkatkan Kemampuan Pemahaman Dan Berpikir Kritis Serta Disposisi Matematis Siswa SMA. Infinity, 2(1), 32.

Utami, F. D., Djatmika, E. T., \& Sadijah, C. (2017). Pegaruh Model Pembelajaran terhadap Pemahaman Konsep, Sikap, Sikap Ilmiah, dan Kemampuan Pemacahan Masalah Matematis Ditinjau dari Motivasi Belajar Siswa Kelas IV. Jurnal Pendidikan, 2(12), 1629-1631.

Yanti, S., \& Surya, E. (2017). Kemandirian belajar dalam memaksimalkan kualitas pembelajaran. December.

Zuraida, Johar, H. (2013). peningkatan pemahaman matematis dan disposisi matematis dengan strategi mathematical habits of mind. 2(1), 32. 